International Journal of Agriculture, Environment and Bioresearch

Vol. 06, No. 05; 2021

ISSN: $2456-8643$

\title{
THE USE OF BIOSTIMULANT IN COCOA'S CULTURE: AN ALTERNATIVE PRACTICAL TO REVERSE PESTICIDES-INDUCED COGNITIVE-BEHAVIORAL IMPAIRMENTS IN POPULATIONS FROM PRODUCTION AREAS?
}

\author{
LALLIE $^{1 *}$ Hermann-Désiré, N'GO ${ }^{2}$ Kouadio Pacôme, DOUMBOUYA ${ }^{3}$ Mohamed and ORO $^{3}$ Zokou Franck $^{\prime}$ \\ ${ }^{1}$ Training and Research Unit (UFR) of Biological Sciences, Department of Chemistry-Genetics, Peleforo GON \\ COULIBALY University, BP 1328 Korhogo, Côte d'Ivoire \\ ${ }^{2}$ Training and Research Unit (UFR) of Biological Sciences, Department of Animal Biology, Peleforo GON \\ COULIBALY University, BP 1328 Korhogo, Côte d'Ivoire \\ ${ }^{3}$ Training and Research Unit (UFR) of Biological Sciences, Department of Plant Biology, Peleforo GON \\ COULIBALY University, BP 1328 Korhogo, Côte d'Ivoire
}

https://doi.org/10.35410/IJAEB.2021.5676

\begin{abstract}
Côte d'Ivoire is the worldwide largest cocoa producer. However, cocoa's tree diseases and pests cause more than $60 \%$ production losses. Because of the adverse environmental and human health effects of pesticides and chemical fertilizers, in this study we tested the innovative natural biostimulant Banzaï to minimize those losses. Two kinds of parcels were selected in cocoa's locality of Tafissou in Côte d'Ivoirefor this pilot study: one with an application of the biostimulant Banzaï on a cocoa plant soil with fertilizer using during thethree last years (DAE) and another without any fertilizer during the last three years(DSE). Our results showed thattheplotwith biostimulantBanzaï produced more significantly cherriesand pods than the control plots without biostimulant. Indeed, the progression rate of cherries is between 32 to $104 \%$ in the plotsDSE while it is between 47 to $154 \%$ in theplotsDAE. Also, the pods productionwasbetween 8 and $61 \%$ in plots DSE, but it was in high progression between 74 and $226 \%$ in plots with DAE. This study suggests that the use of the biostimulant Banzaï has positiveactions on the yield of cocoa productivity. In the second part of our project, we will consider an epidemiological approach through questionnaire and neuropsychological tests to assesscognitive-behavioral status impairmentas side effects in population living in cocoa areas with application of biostimulant Banzaï compared to those of cocoa areas with traditional use of pesticides and other agro-chemicals.
\end{abstract}

Keywords: Banzaï, Biostimulant, Cocoa culture, Productivity improvement ,cognitivebehavioral profile, Côte d'Ivoire.

\section{INTRODUCTION}

Currently, the major challenge for thefarming community is to feed a world population steadily in increasing, with an estimation to 10.5 billion people by 2050 . However, the global climate change, water salinization, advancement of desertification, the natural erosion and the reduction of arable land or finding new areas for agricultural practice represent various compelling factors(Tripathi et al.,2019). As palliative solutions, the use of agro-chemicals and organic fertilizer are widely recommended (Carvalho, 2006; Szentpétery et al.,2005). However, in recent decades, while the phytosanitary products improved the quantity and quality of global 
food production, they are considered as serious environmental contaminants(Carvalho, 2006; Ramankutty, 2018). In addition, previous studies have reported that agro-chemicals impact negatively on nutritional and nutraceutical quality of agricultural products (Carvalho, 2006; Ramankutty, 2018) as well as are potential risks for human health in long-term (Pandey et al., 2020). Therefore, alternative methods based on the use of bio stimulants demonstrate a great interest for the farmers, the markets and the scientific community. The biostimulants stimulate plant growth and physiology, increase tolerance to abiotic stress (Kerchev et al., 2020; Omidbakhshfard et al., 2020), resistance to biotic and pathogenic stress (Chrysargyris et al., 2018). In addition, the biostimulants based on natural products is increasingly in the line with the objectives of sustainable development since it could limit the adverse effects on environment and health. Many of natural biostimulants are originating from on beneficial microorganisms, seaweed extracts, protein hydrolysates, amino acids among many others (Rouphael and Colla,2018; Bulgari et al.,2019).

Côte d'ivoire is the world's leading cocoa producer with about 1,600,000 tons, or $40 \%$ of global supply, making it the world's leading producer (Koua et al., 2018). However, cocoa tree diseases and pests are rampant in all regions and can cause production losses of up to 60\% (Coulibaly et al, 2017). Indeed, this country is still very dependent on a system of agricultural practice with high use of insecticides and other forms of organic inputs. It is in this context that the natural biostimulant Banzaï, a biostimulant with multiple actions, is produced in Côte d'Ivoire to promote flowering, limit the fall of flowers and cherries and stimulate the vigor of pods against diseases and external stresses (Callivoire, 2017). This study is carried out in the sustainable development framework. It was about to highlight the probable beneficial actions of thebiostimulant Banzaï on the productivity and quality of cocoa. Afterward, we will attempt to know whether the use of biostimulant Banzaï has harmless effects on cognitive-behavioral performances in local living population when compared to those of traditional agro-chemicals dependents including pesticides and fertilizers. In the step of our investigation, the cocoa site of Tafissou (Toumodi, Côte d'Ivoire) has been chosen to test the effect of biostimulant Banzaï on the cherries production and their transformation rateto cocoa's pods.

\section{METHODOLOGY}

\subsection{Study site}

Our study was carried out in Tafissou, a village located on the Djékanou - Bringakro way in the department of Toumodi (Figure 1). The department of Toumodi is $198 \mathrm{~km}$ far from Abidjan (economic capital of Côte d'Ivoire) and $34 \mathrm{~km}$ far form Yamoussoukro (political and administrative capital) (AIP, 2013), and extended on about 2,837 $\mathrm{km}^{2}$. Toumodiis one of the great cocoa producer areas of Côte d'Ivoire. For instance, it was about 8,727 tons of cocoa during the campaign 2012(AIP, 2013). 


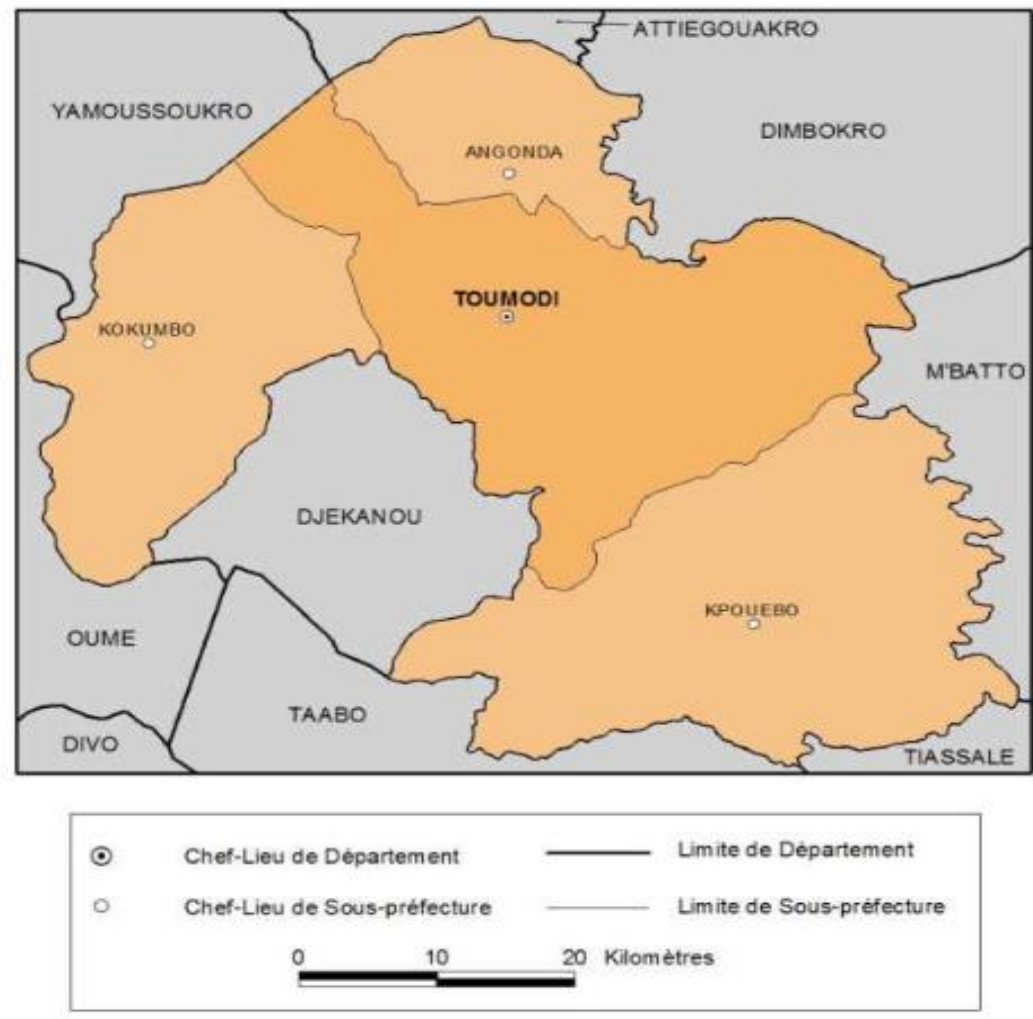

Figure 1: Map of Toumodi (RGPH, 2015)

\subsection{Materials}

The plant material consisted of cocoa trees with at least 10 years old, ripe pods and cocoa beans of the forastero types; and banana leaves were used for the fermentation of cocoa beans. The technical equipment is as following: thereference product to be tested Banzaï; fertilizers adopted for cocoa production; an atomizer to apply the biostimulant Banzaï to cocoa trees; a decameter to delineate the experimental blocks; ribbons and paints to mark the trees.

\subsection{Methods}

In the study area, there are two devices selected. A device without precedent fertilizer used (DSE) and another device with precedent fertilizer used (DAE). The previous no fertilizer consisted of a field of cocoa trees that has received no input of fertilizer during the last three years, while the previous fertilizer consists of a field of cocoa trees that has received a supply of fertilizers during the last three years.

Our two devices consist of three Fischer blocks. Each block is composed of six (6) randomized plots denoted T01, T02, T1, T2, T3 and T4(Figure 2). Each experimental plot is composed of twenty (20) cocoa trees.

- T01 represents the control without application of Banzaï but with a contribution of fertilizer. 
- T02 represents the control without application of Banzaï without fertilizer input.

- $\quad \mathrm{T} 1$ is a plot that has received three applications of Banzaï with a contribution of fertilizer.

- $\mathrm{T} 2$ is a plot that has received four applications of Banzaï without fertilizer input.

- T3 is a plot that received three applications of Banzaï without fertilizer input

- T4 is a plot that has received four applications of Banzaï with fertilizer input.

The observations were carried out during nine months (from July to February). The total number of cherries (immature pod less than $6 \mathrm{~cm}$ in length) is first counted per tree. The pods (size greater than $6 \mathrm{~cm}$ in length) produced since the first treatment of Banzaï was counted, then marked by strings at the level of the peduncle. The counted cherries and pods are not cumulative.

\begin{tabular}{|c|c|c|c|c|c|c|}
\hline T01 & T02 & T1 & T2 & T3 & T4 & Bloc 1 \\
\hline T01 & T02 & T1 & T2 & T3 & T4 & Bloc 2 \\
\hline T01 & T02 & $\mathrm{T} 1$ & $\mathrm{~T} 2$ & T3 & T4 & Bloc 3 \\
\hline
\end{tabular}

Figure 2: Experimental device for the study of the effect of the biostimulant Banzail on the productivity of cocoa trees

\subsection{Statistical analysis}

The statistical analysis was performed using SPSS software version 20 and R 3.2.5. For this purpose, several statistical tests were performed: the Shapiro-Wilk test used for the verification of normality of the distributions. For homogeneous variances, one-way analysis of variance (Anova) was applied while non-normal distribution the nonparametric test of Kruskall-Wallis was done. Then, a classification of treatments according to the levels of differences in treatments was made.

\section{RESULTS}

\subsection{Cherries's production on DSE device}

The figure 3 depictsthe variation in the number of cherries produced by month for one year in the DSE. The highest production of cherries is observed in the month of August with 1,383 cherries. Over the entire observation period, the T1 treatment produces the greatest number of cherries $(1,429)$. Overall, the plots treated by the biostimulant Banzaï have a higher production of cherries than that of the controls in the unprecedented fertilizer device. 


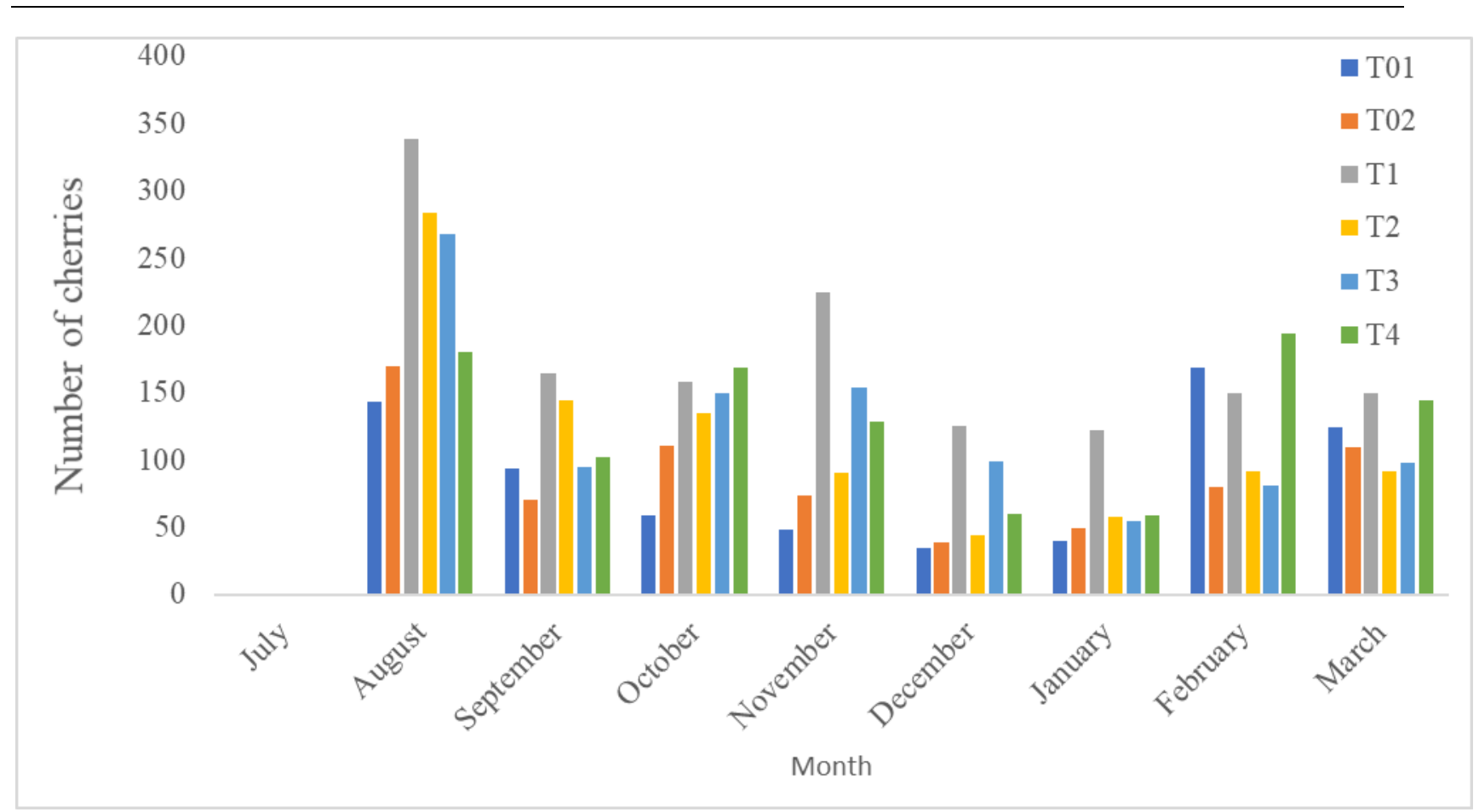

Figure 3: Evolution of the number of cherriesby treatment and per month of observation in the DSE device

Thefigure4 shows boxpots of the number of cherriesby treatment in the DSE device. The Kruskal-Wallis test shows that there is a significant difference between the treatments regarding to the production average of cherries $(\mathrm{p}<0.05)$. The cherries produced are higher in plots with Banzaï treatment than in control plots in the unprecedented fertilizer device.

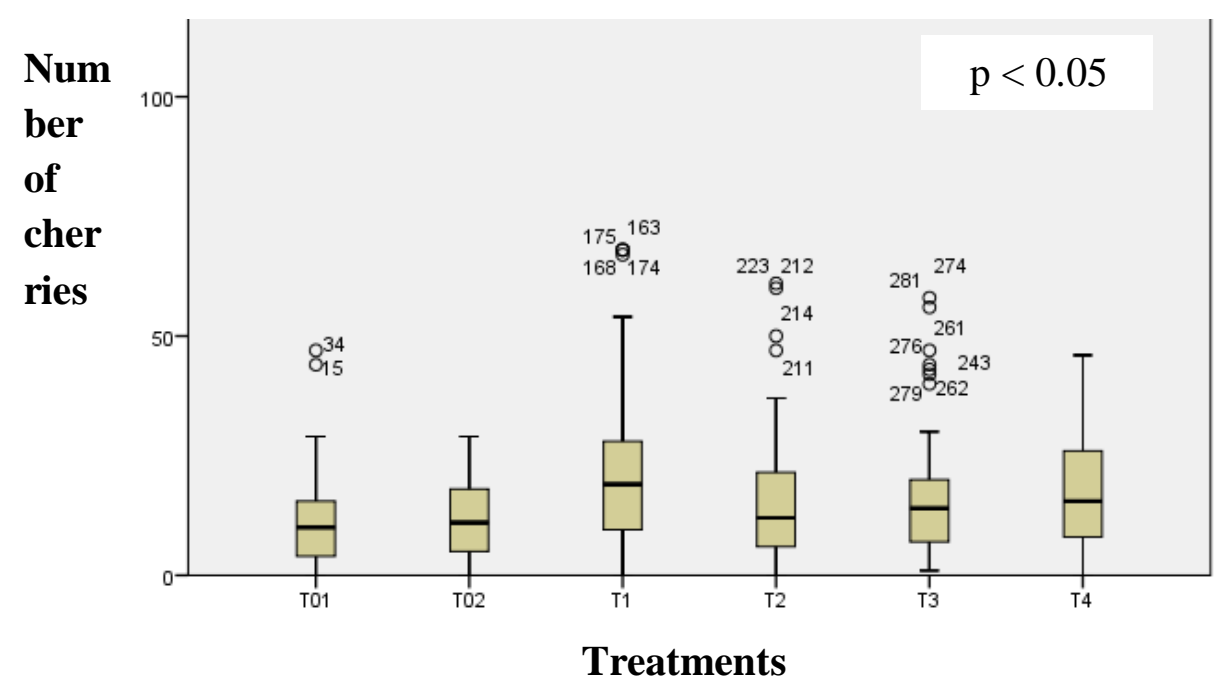


Figure 4: Boxplots of the number of cherries produced by treatment in the DSE device

The Kruskal-Wallis test enables to group the treatments into three descending ranks A, B and C. The T1, T2, T3 and T4 treatments of classes A and B representing the largest averages of production of cherries while the controls (T01 and T02) of class $\mathrm{C}$ which has the lowest averages of cherries produced by treatment (Table 1). The most important production of cherriesis at the T1 treatment level.

Table 1: Classification of treatments according to averages of cherries produced in the DSE system

\begin{tabular}{|ccc|}
\hline Treatments & $\begin{array}{c}\text { Averagde of } \\
\text { Cherries } \\
\text { produced }\end{array}$ & Classification \\
\hline T1 & 23,82 & $\mathbf{A}$ \\
T4 & 17,25 & $\mathbf{B}$ \\
\hline T3 & 16,67 & $\mathbf{C}$ \\
T2 & 15,62 & \\
\hline T01 & 11,83 & \\
T02 & 11,68 & \\
\hline
\end{tabular}

\subsection{Cherries's production on DAE device}

The figure 5 showsa variation in the number of cherries produced in term of the observation period in the DAE. The highest productions of cherries are observed in August and November with an average production of 3,429 cherries. The number of cherries produced is significantly identical over all the other months of observation. T1 treatment produced the highest number of cherries $(4,110)$, followed by T4 treatment $(3,977)$. In general, the plots treated with Banzaï produced a greater number of cherries than the control plots on each month of observation in the device with previous fertilizer. 


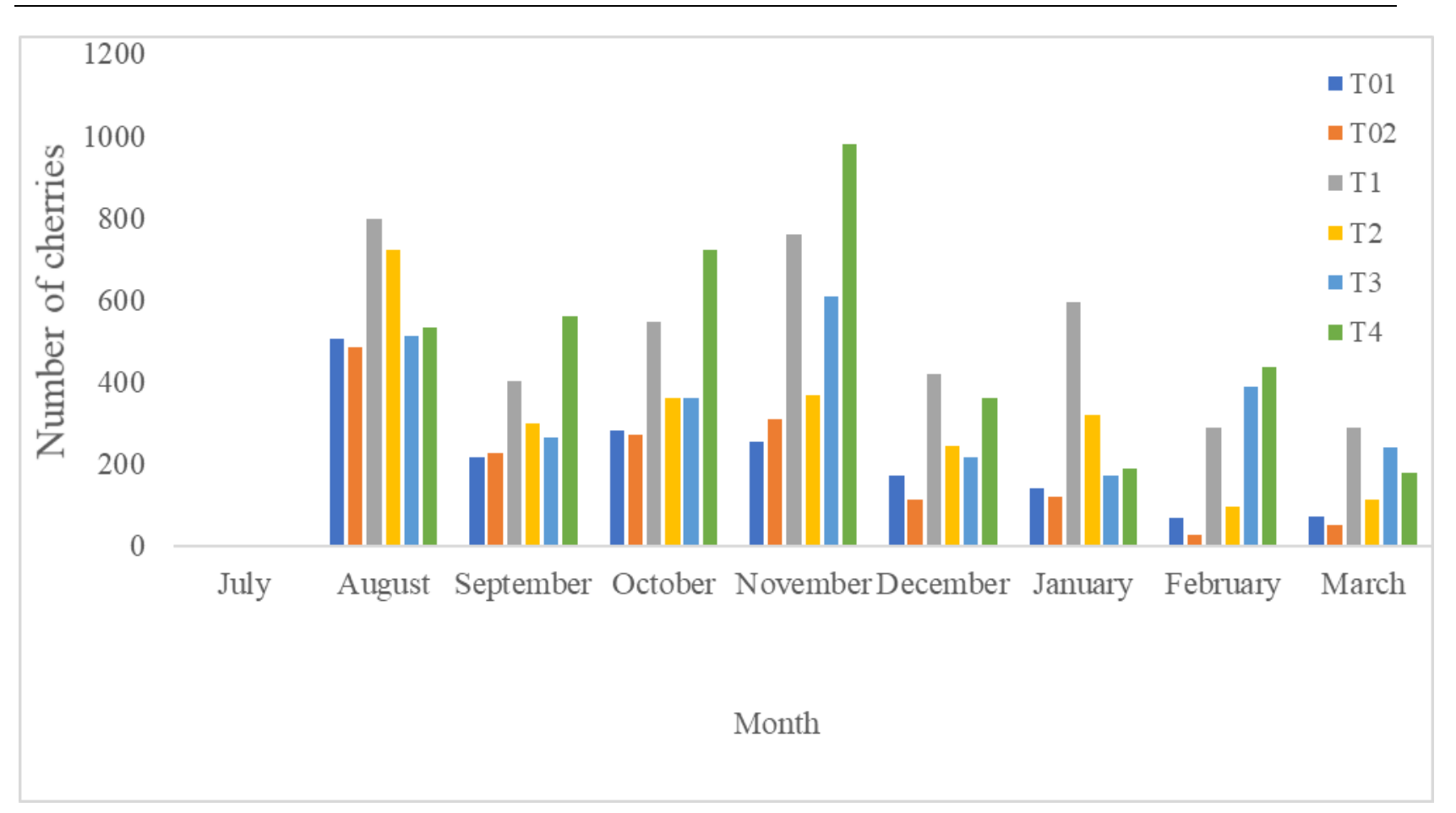

Figure 5:Evolution of the number of cherries by treatment and per month of observation in the DAE device.

Figure 6 shows boxplots of the number of cherriesby treatment in the DAE device. The KruskalWallis test used to compare the production averages of the cherries shows that there is a significant difference $(\mathrm{p}<0.05)$ between the treatments. The cherries produced are higher in the plots with Banzaï treatment than in the control plots in the device with previous fertilizer.

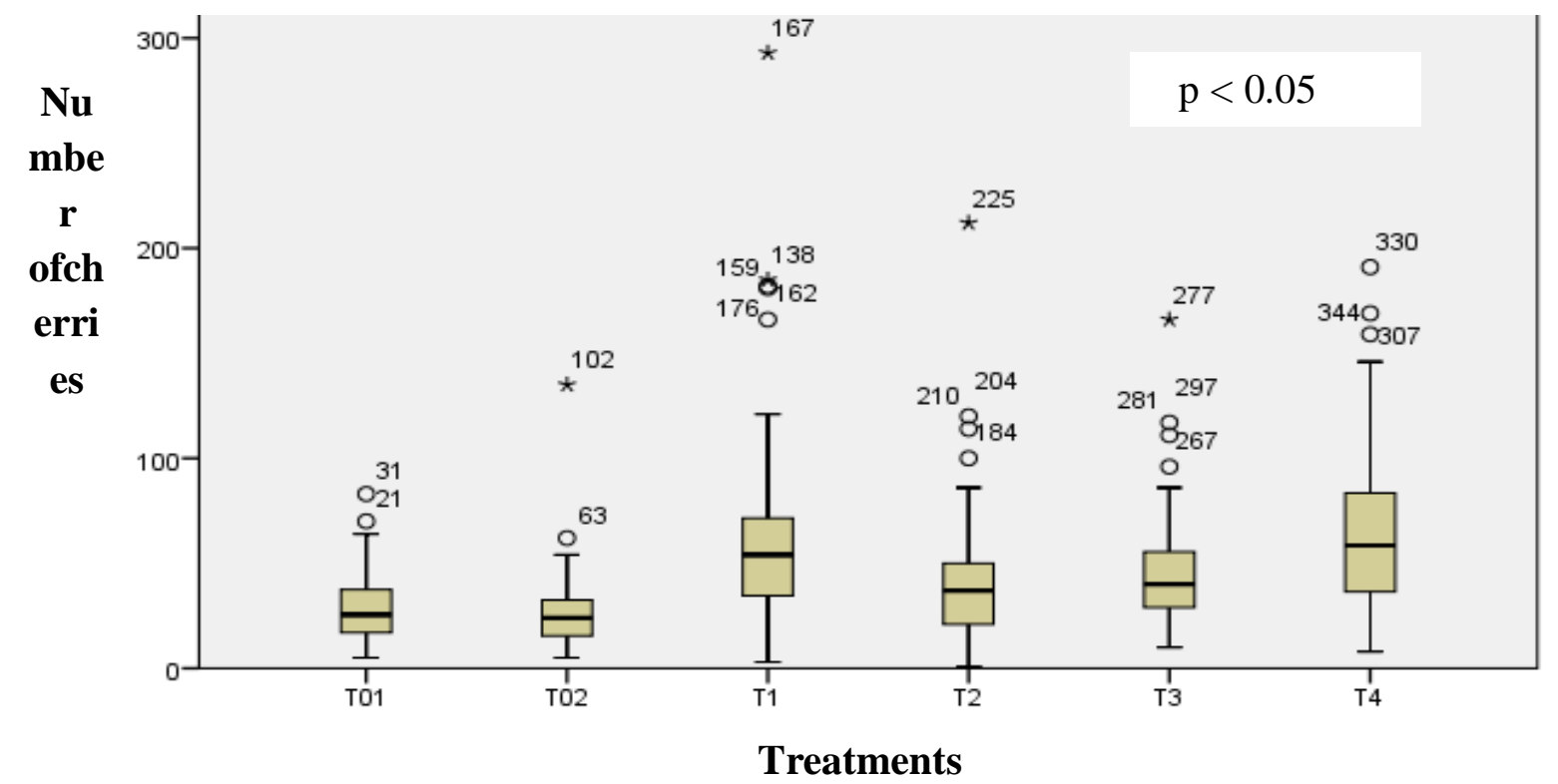


Figure6:Boxplots of the number of cherries produced by treatment in the DAE device

The Kruskal-Wallis test enabled to group the treatments into two descending classes A and B. The controls $\mathrm{T} 01$ and $\mathrm{T} 02$ of class $\mathrm{C}$ which have the lowest averages of cherries produced by treatment while the treatments $\mathrm{T} 1, \mathrm{~T} 2, \mathrm{~T} 3$ and $\mathrm{T} 4$ of classes $\mathrm{A}$ and $\mathrm{B}$ representing the largest averages of production of cherries (Table2). The most important production is found in $\mathrm{T} 1$ and T4 treatments.

Table2: Classification of treatments according to averages of cherries production in the DAE device

\begin{tabular}{|ccc|}
\hline Treatment & $\begin{array}{c}\text { Average } \\
\text { cherries } \\
\text { produced }\end{array}$ & Classification \\
\hline T1 & 68,50 & A \\
T4 & 66,28 & \\
\hline T3 & 46,25 & B \\
T2 & 42,32 & \\
\hline T01 & 28,72 & C \\
T02 & 26,92 & \\
\hline
\end{tabular}

\subsection{Cherries's production by device (DSE vs DAE)}

The figure 7 shows boxplots of the number of cherries depending on the device. The KruskalWallis test used to compare the production averages of the hoppers shows that there is a significant difference $(p<0.05)$ between the devices. The averages of cherries produced are twice as high on the plots of the device with previous fertilizer (DAE) as on the plots of the unprecedented fertilizer device (DSE). 
Vol. 06, No. 05; 2021

ISSN: $2456-8643$

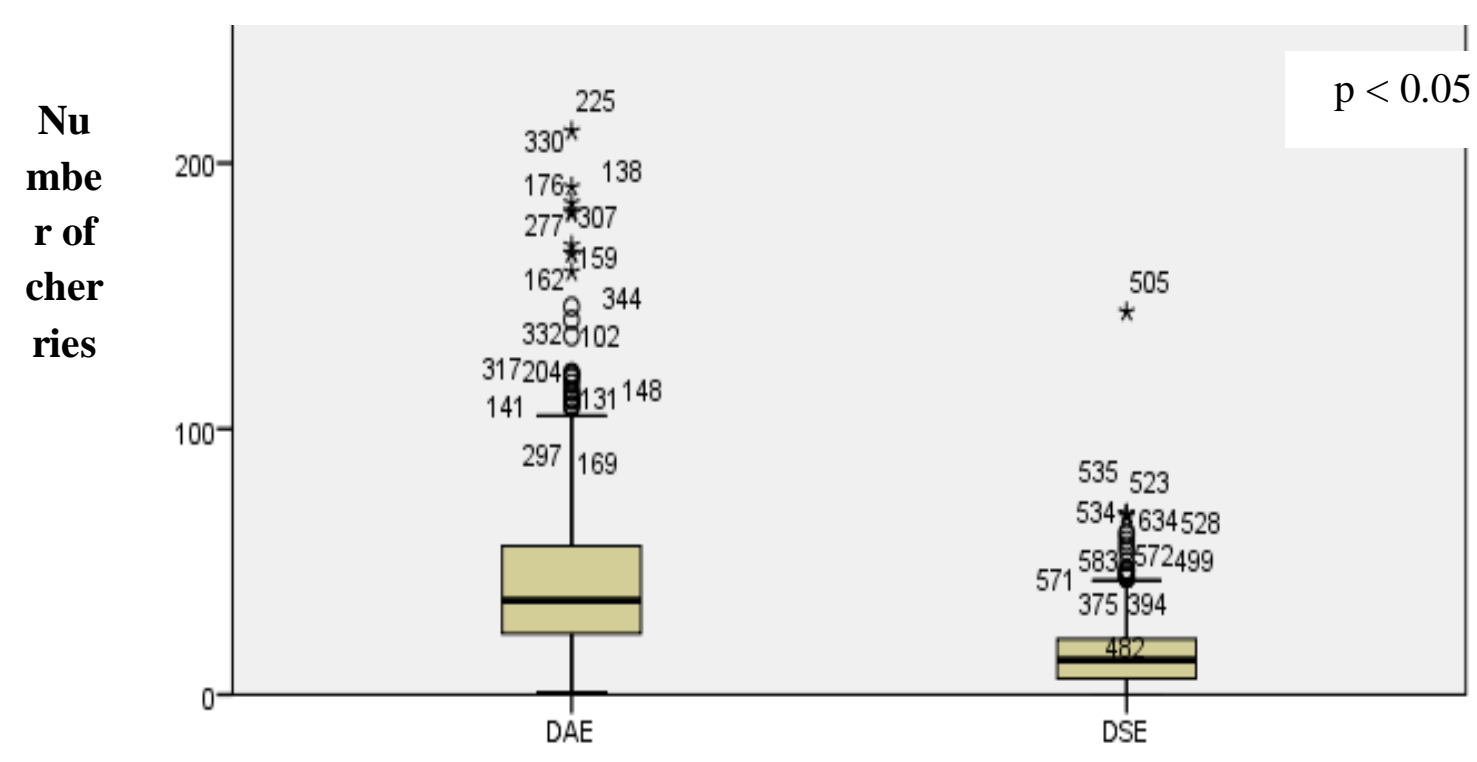

Figure7:Boxplots of the devices according Devices fcherries

\subsection{Pods's production in DSE device}

The figure 8 shows that there is a variation in the number of pods from one treatment to another over the entire observation period in the DSE device. The largest numbers of pods produced are observed in the month of September with 117 pods. The month of March records the lowest number of pods (16). Over the entire observation period, the pod production of plots treated with Banzai is higher than that of the controls (T01 and T02) in the unprecedented fertilizer device.

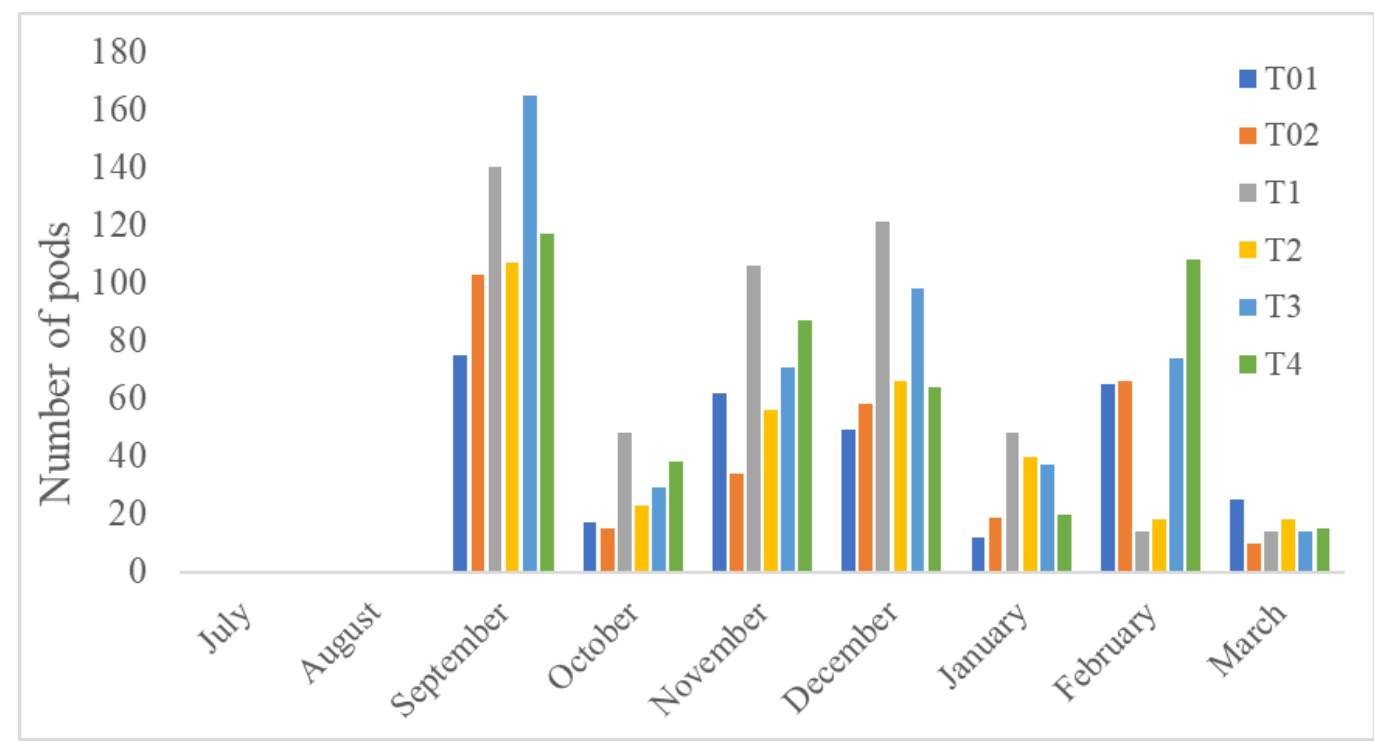

Figure8: Evolution of the number of pods produced by treatment during the months of observation in the DSE device 
Figure 9 shows boxplots of the number of pods depending on the treatment in the DSE device. The Kruskal-Wallis test used to compare the production averages of the pods shows that there is a significant difference $(\mathrm{p}<0.05)$ between the treatments. The pods produced are higher in plots with Banzaï treatment than in control plots in the unprecedented fertilizer device.

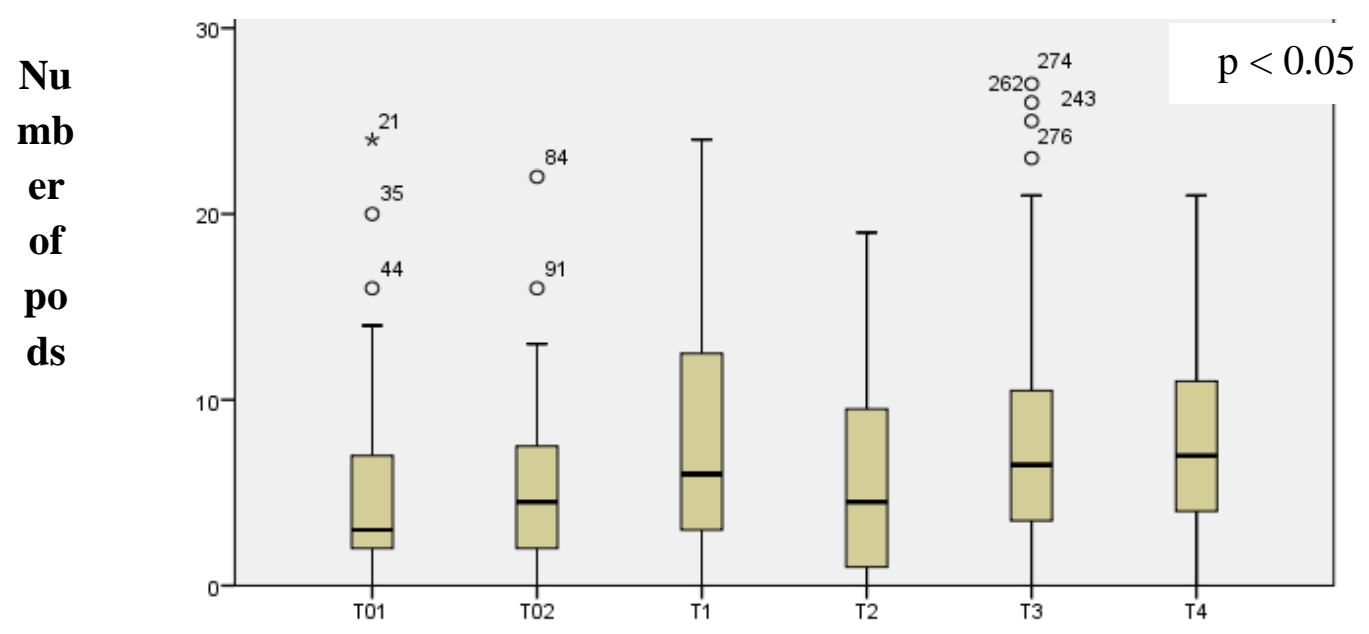

Figure 9: Boxplots of the number of por Treatments the DSE device

The Kruskal-Wallis test made it possible to group the treatments into two descending classes A and $\mathrm{B}$. The T1, T3 and T4 treatments of class A representing the largest averages of production of pods while the controls (T01 and T02) and the T2 treatment of class B which has the lowest averages of pods produced by treatment (Table 3 ). The most important production is found in T1 and $\mathrm{T} 3$ treatments.

Table 3:Classification of treatments according to average pod production in the DSE device

\begin{tabular}{ccc}
\hline Treatments & $\begin{array}{c}\text { Average } \\
\text { of pods } \\
\text { produced }\end{array}$ & Classification \\
\hline $\mathrm{T} 1$ & 8,18 & $\mathbf{A}$ \\
$\mathrm{T} 3$ & 8,13 & \\
\hline $\mathrm{T} 4$ & 7,48 & $\mathbf{B}$ \\
$\mathrm{T} 2$ & 5,47 & \\
$\mathrm{~T} 01$ & 5,08 & \\
$\mathrm{~T} 02$ & 5,08 & \\
\hline
\end{tabular}

\subsection{Pods's production in DAE device}


Figure 10 shows that the first pods were recorded in September with a number of 331. The month of December presents the largest production of pods (451). Plots treated with Banzaï produced a greater number of pods (on average 211) compared to the controls (94) in the device with previous fertilizer (DAE).

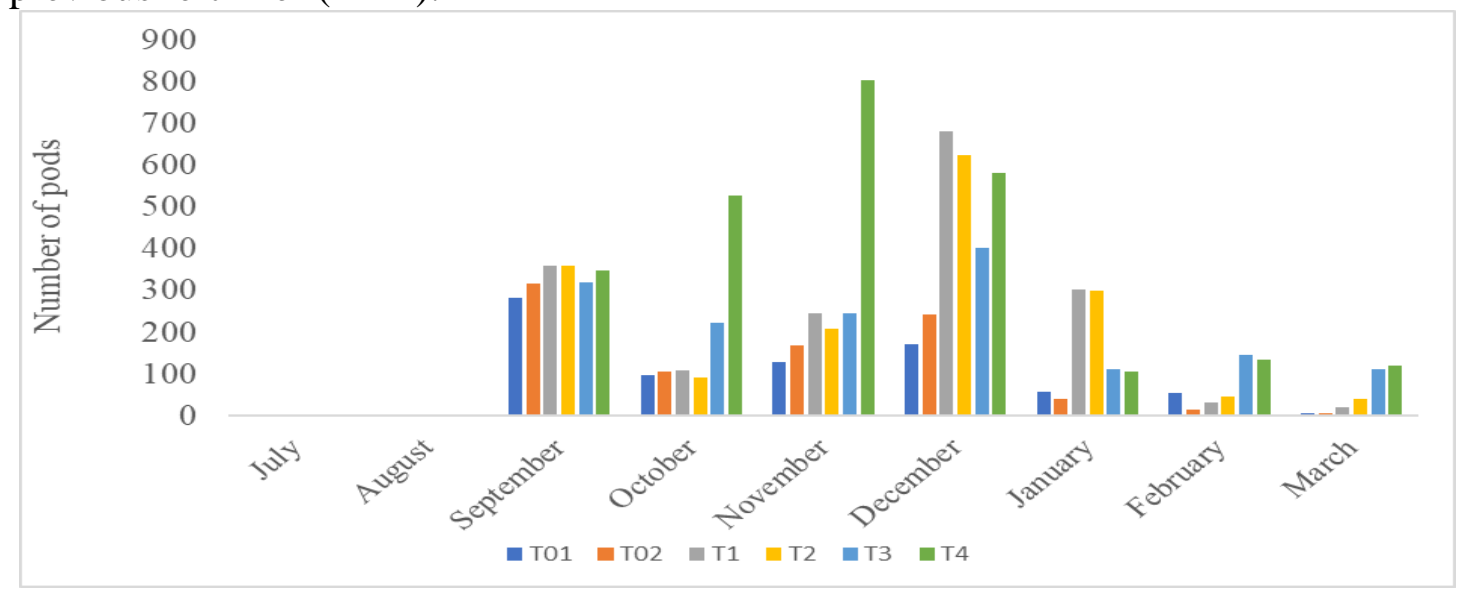

Figure 10: Evolution of the number of pods produced by treatment and per month of observation in the DAE device.

The figure 11 showsboxplots of the number of pods by treatment in the DAE device. The Kruskal-Wallis test used to compare the production averages of pods shows that there is a significant difference $(\mathrm{p}<0.05)$ between the treatments. The pods produced are higher in plots with Banzaï treatment than in control plots in the device with previous fertilizer.

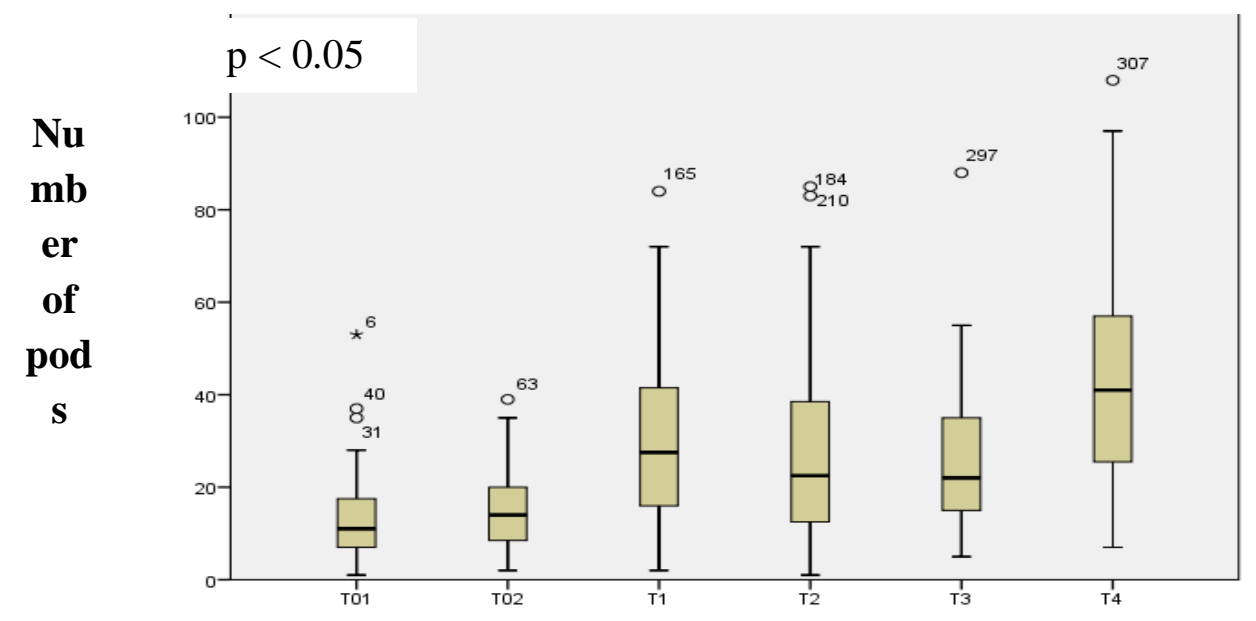

Treatments

Figure 11: Boxplots of the number of pods produced by treatment in the DAE device

The Kruskal-Wallis test made it possible to group the treatments into two descending classes A, $\mathrm{B}$ and $\mathrm{C}$. The T1, T2, T3 and T4 treatments of class A and B representing the largest average of pods production while the controls (T01 and T02) of class $\mathrm{C}$ which has the lowest averages of 
pods produced by treatment (Tab 4). The most important production is found at the level of T4 and $\mathrm{T} 1$ treatments.

Table 4:Classification of treatments according to average pod production in the DAE device

\begin{tabular}{|ccc|}
\hline Treatments & $\begin{array}{c}\text { Pods } \\
\text { average } \\
\text { number }\end{array}$ & Classification \\
\hline T4 & 43,73 & A \\
T1 & 29,27 & \\
\hline T2 & 27,92 & B \\
T3 & 26,05 & C \\
\hline T02 & 14,97 & \\
T01 & 13,38 & \\
\hline
\end{tabular}

\subsection{Pods's production by device (DAE vs DSE)}

Figure 12 shows boxplots of the number of pods by treatment. The Kruskal-Wallis test used to compare the production averages of the pods shows that there is a significant difference $(\mathrm{p}<0.05)$ between the two devices. The average pods produced are twice as high on the plots of the device with previous fertilizer (DAE) as on the plots of the unprecedented fertilizer device (DSE).

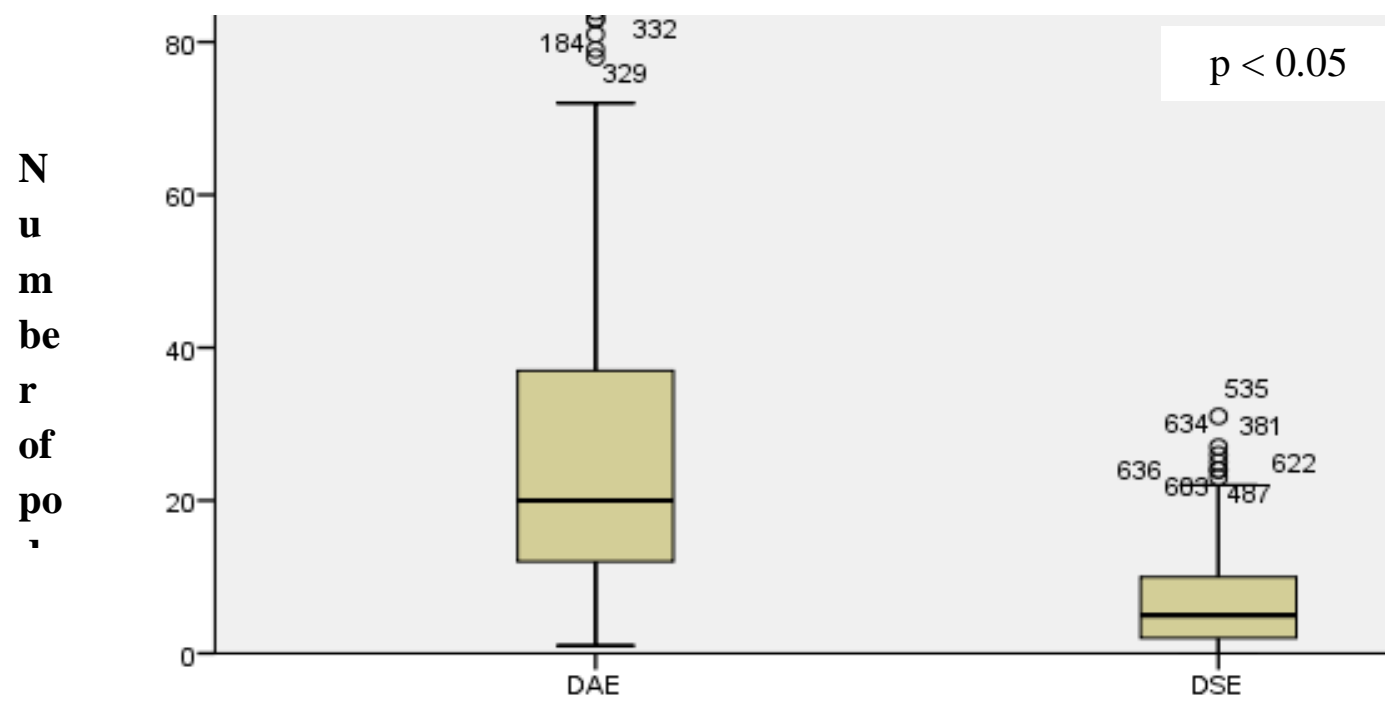

Figure 12: Boxplots of number of pods produc

Devices 
Vol. 06, No. 05; 2021

ISSN: $2456-8643$

\section{DISCUSSIONS}

The evolution of the number of cherriesby treatment during the months of observation showed that the peak of production occurred in the month of August. This can be explained by the rainy season from April to June, which allows the production of cherries. Indeed, according to a report of CNRA, the production of cherries increases significantly after the rainy periods (CNRA, 2009). The production of cherries by treatment and by device showed a significant difference. Indeed, the plots treated with Banzaï have produced significantly more cherries than the control plots without application of the biostimulant. This is in line with Faessel(2014) and his collaborators findings mentioning that the biostimulants use promote the increase of fruits number by limiting the flowers fallen. Also, it has been reported that the application natural biostimulant extracted from seaweed or yeast fungi on tomato plants leaded to improve the fruit quality as well as given a better nutritional value for human health when compared to untreated plants (Giuseppe et al.,2020).Those authors evoked that those natural biostimulants reduced the ripening time and size of tomatoes, thus increasing their marketable supply.

The evolution of the number of pods by treatment during the months of observation showed that the peak of pods production occurred in the month of September. That can be explained by the rise of cherries production the previous month (i.e. august) which in turn transforming into pods. The cherries become pods when the size is about ten centimeter of length (generally more than 6 centimeters). The growth time from cherries to podscan last two to four weeks (Barel et al., 2017). Otherwise, the production of the pods by treatment showed a significant difference. In fact, the plots with application of Banzai produced significantly more pods than the control plots without application of the biostimulant. This is in a line with Faessel's findings which support that biostimulant improves the plants physiology by promoting flowering, thereby stimulating fruit resilience against external aggressive agents and stress (Faessel et al., 2014). The production of cherries and pods in the devices without previous fertilizer (DSE) and with previous fertilizer (DAE) use showed a significant difference. Indeed, plots with previous fertilizer used presented the highest cherries and pods production compared to that without any previous fertilizer used. That could be due to the effects of fertilizers accumulated in the soil leading to improvement of the production yield. Similarity, Goulet et al (1997) reported that the previous use of fertilizer in the plot enabled a significant production of cherries and pods. Even if the use of agrochemicals demonstrates beneficial actionsby increasing the crops yield, the subsequent deleterious effects onfruit quality, environment and human health remain a recurrent issue (Szentpétery et al., 2005). For this reason, in ivorian context, the « Fairtrade » organization sensitizes through local cooperative about the technical to handle safety the pesticides and fertilizers in cocoa agricultural practice. Otherwise, several actions undertaken helped to aware the risk of toxicity on environment as well as the human health. That permitted to reduce the incidences of acute toxicity due to pesticide among the farmer predominantly in the smallholders. However, a recent report done some Ivorian southeastern cooperative, certified by " Fairtrade », suggested the norms of their actions on long lasting human and environment effects seem to be inappropriate (Sellare et al., 2020). In fact, there are too much of aging coco's orchard southeast areas of Ivory coast, poverty of the soils, and high incidence plant diseases due to diverse pests including stem borers, miridae, swollen shoot virus (Foundjem-Tita et al., 2017). Furthermore, it has been reported that chronic exposure to environmental concentrations of organophosphorus insecticides caused cognitive-compartmental, emotional and psychomotor disorders including memory and 
attention deficits, lowering of vigilance level, anxiety and depression (Ismail et al., 2012; Kori et al., 2018).Therefore, in the second part of our investigation, we will consider through a crosssectional epidemiological and toxicological approaches based onenvironmental exposure to agrochemicals assay and neuropsychological tests, the possible relationship between cognitivebehavioral profile and the level of fluids toxicants. We will emphasize on a compared study betweenproducers and relatives living in cocoa's area traditionally using for one side only natural biostimulant Banzaï and other side the organicinsecticides and/or fertilizer inthe agricultural practice system.

\section{CONCLUSION}

We have shown that the application of the natural biostimulant Banzai in the cocoa locality of Tafissou promotes significant increase of the cherries productivity, with a rate between 32to $104 \%$ on unprecedented plots of fertilizer and between 47 to $154 \%$ in plots with previous fertilizer compared to the controls. The application of Banzaï has also a significant effect on the production of pods with a margin of increase between 8 to $61 \%$ in the plots without previous fertilizer and between 74 to $226 \%$ in the plots with previous fertilizer compared to the controls.

The use of biostimulant Banzaï could therefore replace the role of pesticides and other forms of agro-chemicals since it improved the quantity of productivity maybe the quality of cocoa. We hypothesize that it limitsthe detrimental effects on the environment and health in general, and on cognitive-behavioral health in particular. This will be the subject of our next approach to address.

\section{REFFERENCES}

Agence Ivoirienne de Presse (AIP), 2013: Monographie du département de Toumodi. Abidjan.Net. date de visite :22/12/2018. 5p.

Barel M., 2017 : Le cacaoyer et les cabosses de cacao (fleurs, couleurs...). Planète. p1-4.

Bulgari R.; Franzon G.; Ferrante A., 2019: Biostimulants application in horticultural crops under abiotic stress conditions. Agronomy, 9:306.

Callivoire, 2017 : Biostimulant Banzaï. Rapport Callivoire. p-2.

Carvalho, F.P., 2006: Agriculture, pesticides, food security and food safety. Environ. Sci. Policy, 9, 685-692.

Chrysargyris, A.; Xylia, P.; Anastasiou, M.; Pantelides, I.; Tzortzakis, N., 2018: Effects of Ascophyllum nodosum seaweed extracts on lettuce growth, physiology and fresh-cut salad storage under potassium deficiency. J. Sci. Food Agric.

CNRA, 2009 : Bien cultiver du cacaoyer en Côte d'Ivoire. Fiche technique cacaoyer. p. 1-4.

Coulibaly K, Kébé B, Aka A, Kouakou K, N'Guessan W, Tahi G.M, Kassin K.E, Guiraud S.B, Assi M, Koné B, N'Guessan K., 2017 : Bien lutter contre la pourriture brune des cabosses du cacaoyer en Côte d'Ivoire. Fiche technique cacaoyer n ${ }^{\circ}$ 6, rapport CNRA, p.1-2.

Faessel L, Gomy C, Nassr N, Tostivint C, Hipper C, Dechanteloup A., 2014 : Produits de stimulation en agriculture visant à améliorer les fonctionnalités biologiques des sols et des plantes. Étude des connaissances disponibles et recommandations stratégiques. Bio by Deloitte et RITTMO Agroenvironnement pour le ministère de l'Agriculture, de l'Agroalimentaire et de la Forêt. $148 \mathrm{p}$. 
Vol. 06, No. 05; 2021

ISSN: $2456-8643$

Foundjem-Tita, D., Degrande, A., Donovan, J., Stoian, D., Kouame, C., 2017: Baseline for assessing the impact of Fairtrade certification on cocoa growers and cooperatives in Côte d'Ivoire. World Agroforestry Center, Nairobi.

Giuseppe Mannino, Cristina Campobenedetto, Ivano Vigliante, Valeria Contartese, Carla Gentile and Cinzia M., 2020: Bertea The Application of a Plant Biostimulant Based on Seaweed and Yeast Extract Improved Tomato Fruit Development and Quality Biomolecules, 10, 1662.

Goulet M, N'Dayegamiye A et Laverdière M., 1997 : Les sciences du sol au 21e siècle. Centre de recherche et d'expérimentation en sols, Ministère de l'Agriculture, des Pêcheries et de l'Alimentation du Québec, 2700 Einstein, Sainte-Foy, Québec, Canada G1P 3W8. 110p.

Ismail AA, Bodner TE, Rohlman DS., 2012: Neurobehavioral performance among agricultural workers and pesticide applicators: a meta-analytic study. Occup Environ Med., 69(7):457-64.

Kerchev, P.; van der Meer, T.; Sujeeth, N.; Verlee, A.; Stevens, C.V.; van Breusegem, F.; Gechev, T., 2020: Molecular priming as an approach to induce tolerance against abiotic and oxidative stresses in crop plants. Biotechnol. Adv., 40:107503.

Koua S, Coulibaly N, Alloué B., 2018 : Caractérisation des vergers et des maladies de cacao de la Côte d'Ivoire : cas des départements d'Abengourou, Divo et Soubré. Journal of Animal \&Plant Sciences. Vol.35, Issue 3: 5706-5714.

Mohammad Amin Omidbakhshfard, Neerakkal Sujeeth, Saurabh Gupta, Nooshin Omranian, Kieran J Guinan, Yariv Brotman, Zoran Nikoloski, Alisdair R Fernie, Bernd Mueller-Roeber, Tsanko S Gechev., 2020: A biostimulant obtained from the seaweed Ascophyllum nodosum protects Arabidopsis thaliana from severe oxidative stress. Int. J. Mol. Sci., 21 (2): 474.

Pandey, S.; Joshi, N.; Kumar, M., 2020: Agrochemicals and human well-being: A review in context of Indian agriculture. Int. J. Cosmet. Sci., 8, 1539-1543.

Rajesh Kumar Kori, Manish Kumar Singh, Abhishek Kumar Jain, Rajesh Singh Yadav, 2018: Neurochemical and Behavioral Dysfunctions in Pesticide Exposed Farm Workers: A Clinical Outcome Ind J Clin Biochem, 33(4):372-381

Ramankutty, N.; Mehrabi, Z.; Waha, K.; Jarvis, L.; Kremen, C.; Herrero, M.; Rieseberg, L.H., 2018: Trends in global agricultural land use: Implications for environmental health and food security. Annu. Rev. Plant Biol., Vol. 69:789-815.

RGPH (Recensement Général De La Statistique La Population Et De L'habitat), 2015: Répertoire des localités : Région du Bélier. INS. 40p

Rouphael, Y.; Colla, G., 2018: Synergistic biostimulatory action: Designing the next generation of plant biostimulants for sustainable agriculture. Front. Plant Sci., 9, 1655.

Sellare, J., E.M. Meemken, M. Qaim, 2020: Fairtrade, Agrochemical Input Use, and Effects on Human Health and the Environment. GlobalFood Discussion Paper 136, University of

Goettingen. http://www.uni-goettingen.de/de/213486.html.

Szentpétery, Z.; Heged "us, Z.; Jolánkai, M., 2005: Impact of agrochemicals on yield quality and pesticide residues of winter wheat varieties. Cereal Res. Commun., 33, 635-640.

Tripathi, A.D.; Mishra, R.; Maurya, K.K.; Singh, R.B.; Wilson, D.W., 2019: Estimates for world population and global food availability for global health. In The Role of Functional Food Security in Global Health; Elsevier: Amsterdam, The Netherlands; pp. 3-24. 